\title{
Assessment of the Physico-Chemical Quality of Water of Oued Ouljat Echatt and Dam Ibn Batouta-Tangier
}

\author{
El Mustapha AZZIRGUE and Farida SALMOUN \\ Physico-chemistry Laboratory of Materials, Natural Substances and Environment (LAMSE) - \\ Tangier-Morocco Faculty of Science and Technology, Morocco
}

\begin{abstract}
The target of our study is to follow the physicochemical quality of raw and purified wastewater by STEP Chrafate in Tangier Morocco. In this unique situation, inspecting was done at 9 stations examination partitioned in two periods: the wet time frame and the dry time frame, each including 9 tests in the shallow waters. The Suspended Matters, Nitrogen, Phosphate, Nitrite, Nitrate and Ammonium are the primary parameters examined so as to build up a finding of condition of the shallow waters contamination in our general vicinity consider.

The examination of these parameters uncovered that the substance of these components remain anyway high and demonstrate, generally, a danger of real contamination of the waters of Oued Ouljat Echatt and Ibn Batouta dam. Be that as it may, the utilization of these waters could represent a noteworthy wellbeing hazard for clients of this water as drinking water, water system, domesticated animals watering and washing.
\end{abstract}

Keywords: Pollution, Physico-chemical analyzes, STEP Chrafate, Tangier Automotive City, Oued Ouljat Echatt, Ibn Batouta dam

\section{INTRODUCTION}

Morocco has recognized weight driven works, since the sixties, this made it possible to have a basic inheritance in water. In any case, this benefit, which was once of good quality, is starting at now undermined by various point and diffuse wellsprings of pollution [5] The creation of industrial zones and free zones in Morocco contributes to the socio-economic development, but a particular interest is granted to the protection and the durable conservation of the Moroccan hydrographic systems, and as for the majority of the countries of the world, Morocco does not It does not escape the scourge of pollution because of wastewater discharges. What constitutes a threat to resources and the health of populations [3]. This remains a major cause of the degradation of the quality of natural waters. Surface waters such as rivers are the place of various abusive discharges of industrial and domestic effluents [2]. The study of the physicochemical quality of the watercourses makes it possible to characterize the mineral elements which degrade the quality of these waters and threaten aquatic life. [10]. It is the concentration of these elements which determines the quality of a water and makes it possible to know if it is suitable for a particular use or not. [8]. A more complete diagnosis of the current situation of the physicochemical quality of water and a rigorous follow-up of its evolution, prove to be of great necessity for the safeguarding of this ecosystem. It is in this perspective that our work falls, the main objectives of which are:

- A physicochemical characterization of the waters of Oued Ouljat Echatt and the dam Ibn Batouta

- A comparative analysis of the different parameters studied in relation to other Oued and dams already studied

- An identification of the different risk factors that could affect the quality of these waters

- An assessment of the quality of these waters with reference to the standards of surface water or irrigation or discharges.

\section{Materials and methods}

\section{II.1. The investigation zone}

Our investigation territory, considered as a critical incorporated mechanical stage, Tanger Automotive City (TAC), the 
new organized commerce zone open mid-2013 close to the Renault manufacturing plant (about 2.6 Km), situated at South-East of Tangier (a long way from Tangier around $17 \mathrm{~km}$ ). The wastewater from this stage is sanitized by the STEP Chrafate which releases its waters in Oued Ouljat Echatt which drives these waters to the Ibn Batouta dam (Fig 1).In expansion, river Ouljat Echatt and Ibn Batouta dam are of major financial significance for the occupants of its bowl in water system and watering (Fig 2). The contemplated area fits between Lambert facilitates: $X=471061, Y=559489$ and $X=475800, Y=563445$. The heights shift from $37 \mathrm{~m}$ at the Ibn Batouta dam to $96 \mathrm{~m}$ (at the STEP Chrafate).

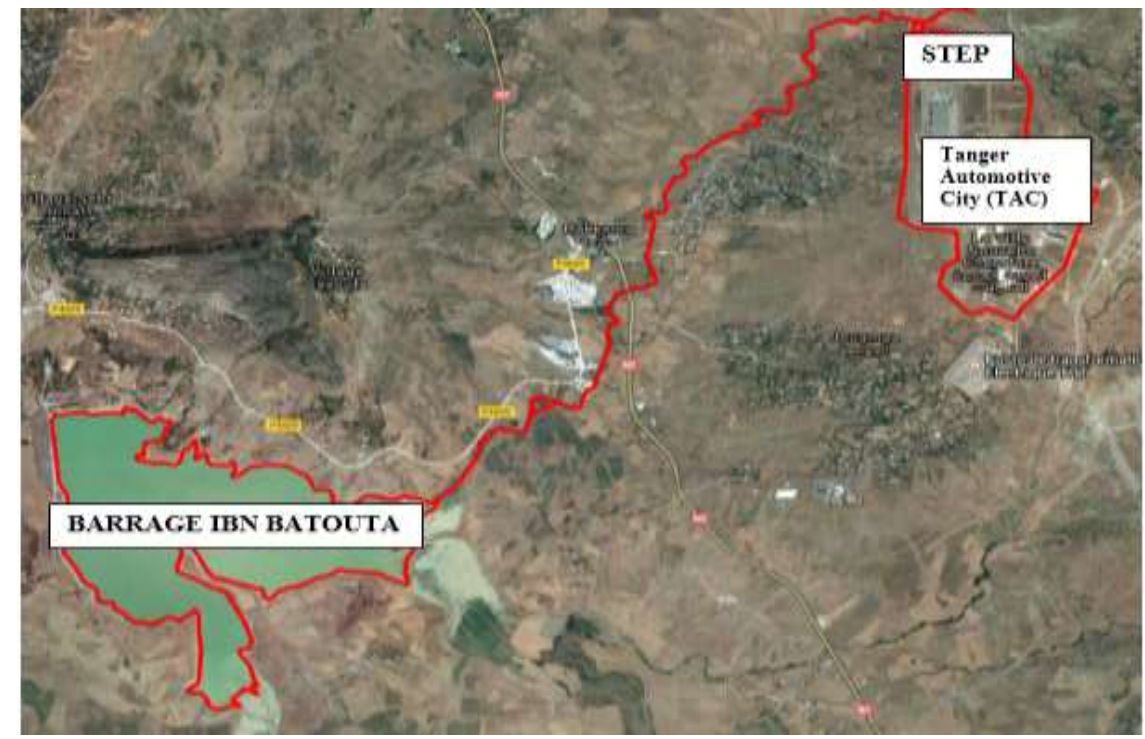

Fig 1: Location of the studied region in the northern part of Morocco (Google Earth extract

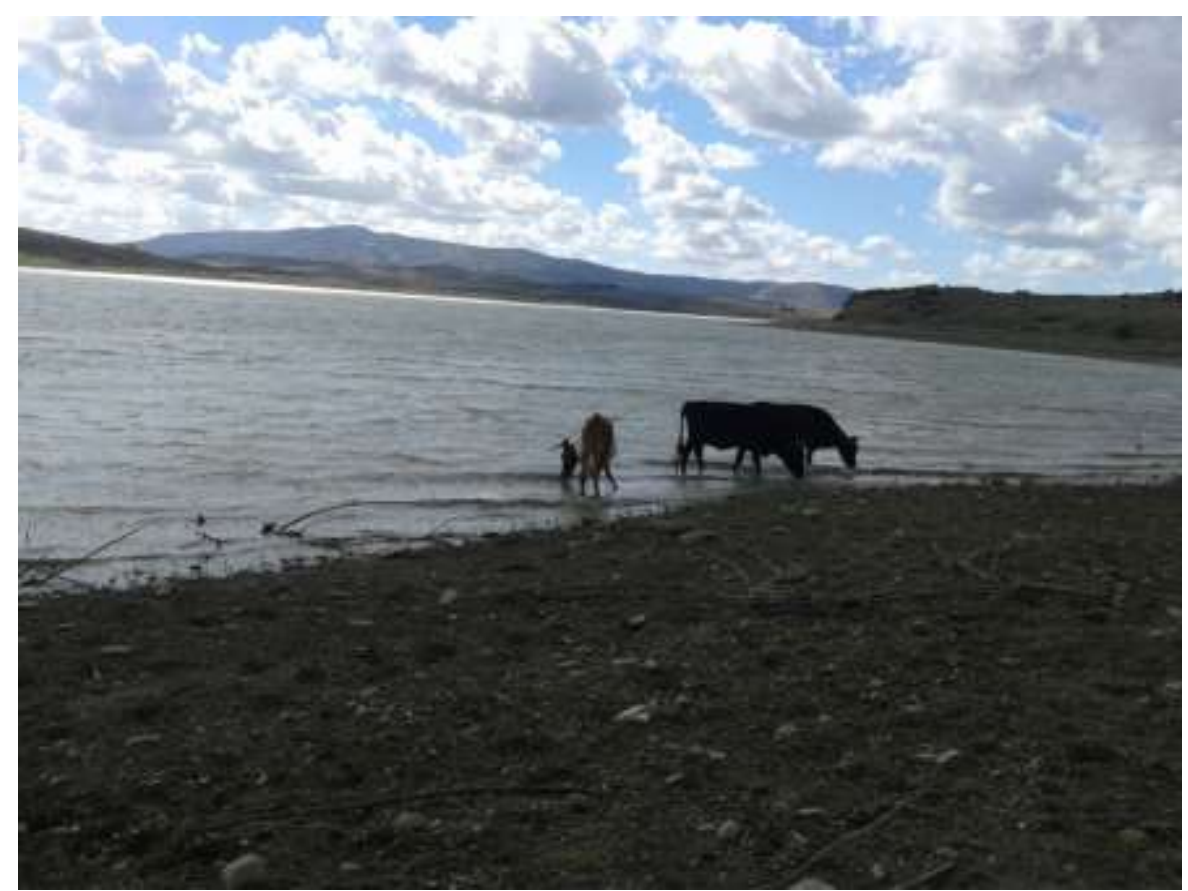

Fig 2: Use of Oued Waters in animal Watering and Irrigation

\section{II.2. Hydrogeological and soil characteristics}

The study site includes Oued Ouljat Echatt as well as several small temporary or torrential tributaries and the Ibn Batouta dam. Geologically, the study area is part of the Rifain domain in northern Morocco containing flysch groundwater in addition to a few units of the external Rif [12]. The study area includes outcrops belonging to the flysch formations, large outcrops of the predominantly clayey Tanger unit forming part of the outer rif in addition to some quaternary formations, mostly alluvial. The study area includes outcrops belonging to the flysch formations, large outcrops of the predominantly clayey Tanger unit forming part of the outer rif in addition to some quaternary formations, mostly alluvial. [17]. 


\section{II.3. The climate}

The study area is characterized by two seasons, one dry and hot and the other wet and cold longer than the first [6]. The climate of the region is subhumid Mediterranean with a mild and humid winter and a warm, dry summer that extends over five months from May to September. The area benefits from the combined influence of two maritime facades (the Mediterranean and the Atlantic) and has an average rainfall of about $765 \mathrm{~mm} /$ year) [15].

\section{II.4. The Sampling sites}

We chose the water sampling points in order to have an overall picture of the study area. We carried out a total of nine samples for the physicochemical analysis of the water distributed as follows: three samples at the entrance of the Ibn Batouta dam and six samples at the level of Oued Ouljat Echatt during the period of December 2016 and July 2017 (fig.3).

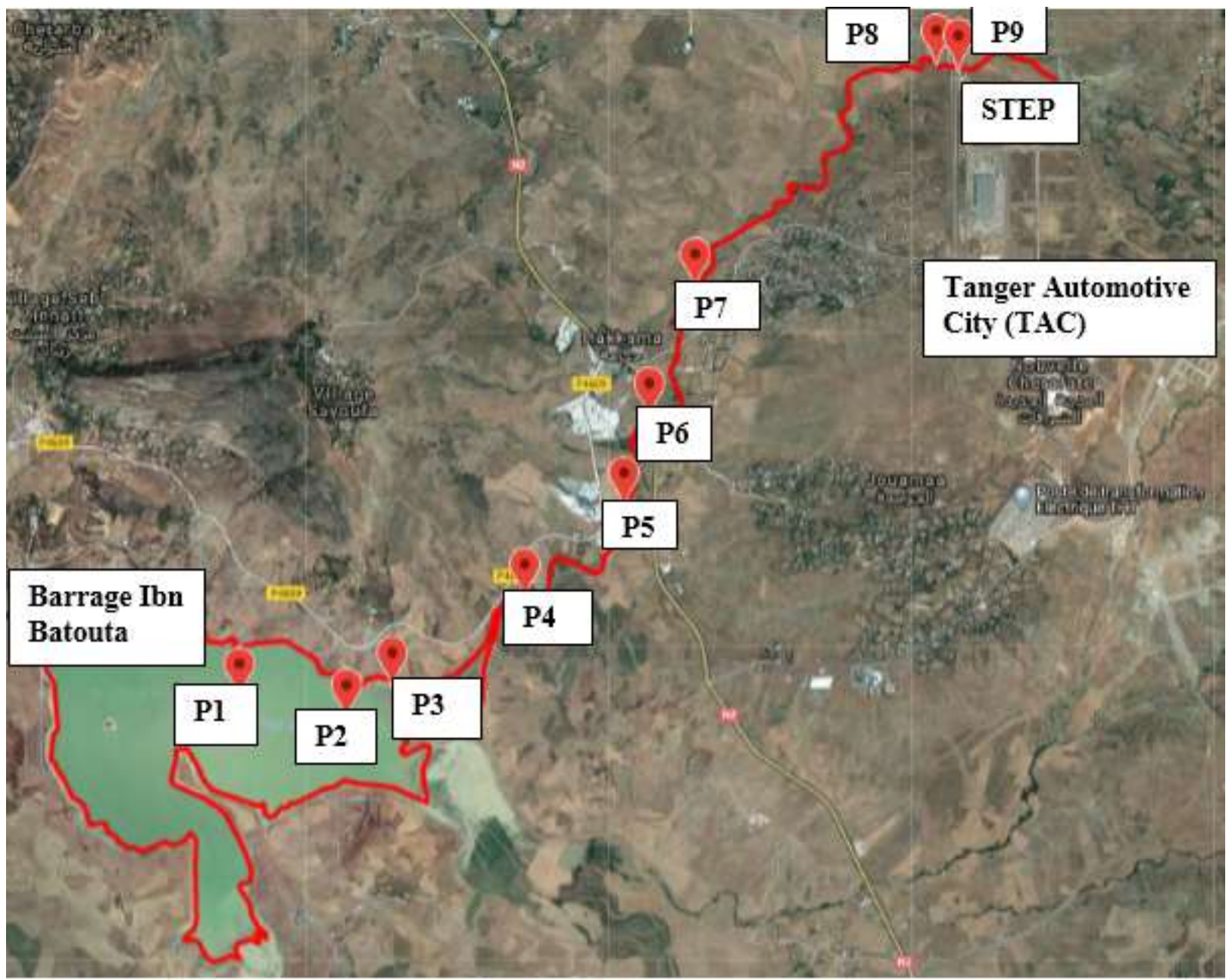

Fig 3: Geographical location of sampling points

\section{II.5. Sampling and sampling frequencies}

In total, we carried out 18 samples for physicochemical analysis. On each sample are tested 5 physical parameters and 12 chemical parameters (Fig 3). A volume of 1.5 liters is taken from polyethylene bottles for physico-chemical analyzes. Before sampling, each bottle was rinsed with the water to be analyzed [11]. Samples were identified by means of sampling data sheets (date, topographical coordinates, sampling time, number, etc.). Laboratory transport of the sampling vials was carried out in a cooler at low temperature $\left(4^{\circ} \mathrm{C}\right)$.

\section{II.6. Parameters studied and methods of analysis of water}

In order to study the waters of the Ouljat Echatt Oued and the waters at the Ibn Batouta dam entrance, we carried out the sampling along the Oued between the WWTP (the wastewater treatment plant) and the dam and at the dam entrance. The following physicochemical parameters have been measured: the Suspended Matters, Nitrogen, Phosphate, Nitrite, Nitrate and Ammonium. The material and methods used for other parameters: 
International Journal of Advances in Scientific Research and Engineering (ijasre), Vol 5 (10), October-2019

- Computer hardware: Google Earth, Excel

- In the field: GPS MAGELLAN, Thermometer, pH meter,

\section{RESULTS AND DISCUSSION}

\section{III.1. MES}

The Suspended Substances represent all the mineral and organic particles contained in the waters. In the study site, there are large variations between the different sampling stations. The Oued waters are classified in the middle class while the dam waters are classified in the good class (fig 4 and fig 5).

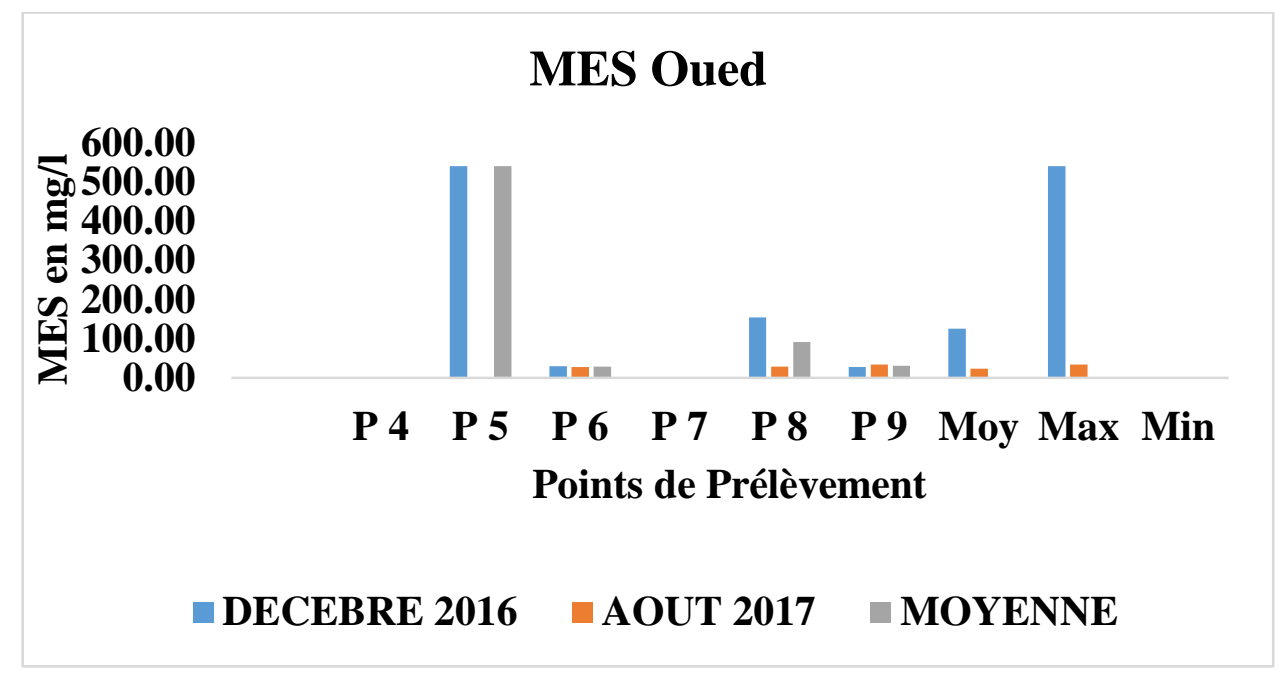

Fig 4 : Spatiotemporal variation of suspended solids measured in Oued waters

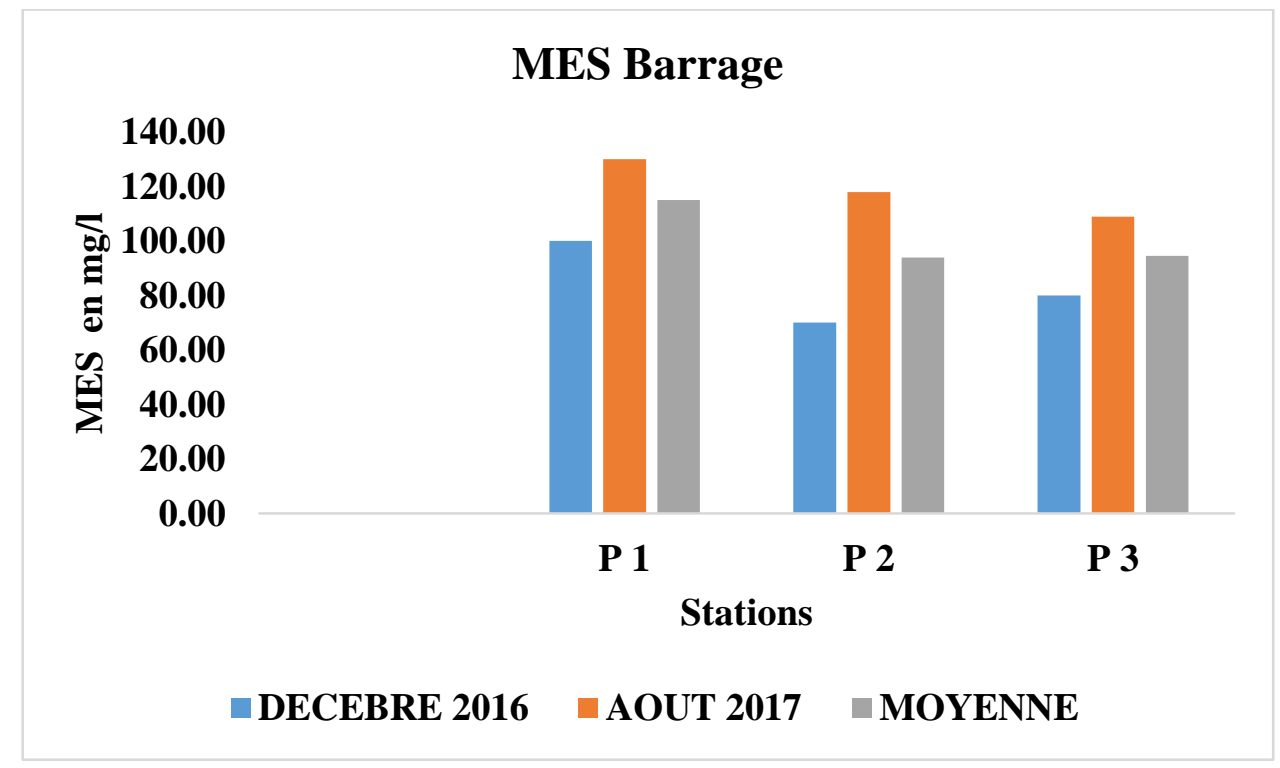

Fig 5: Spatiotemporal variation of suspended solids measured in dam water

\section{III.2. Turbidity}

Turbidity is caused by materials such as clay, silt, fine organic and inorganic matter, plankton and other microscopic organisms suspended in water. [11] The evaluation of the abundance of these particles measures its turbidity [16]. The unit of measure is NTU (Nephelometric Turbidity Unit) in the study area, turbidity varies from $1.16 \mathrm{NTU}$ to $212 \mathrm{NTU}$. The turbidity varies between sampling points depending on the season and reaches the maximum in point 8 in the Oued and P1 in the dam (Fig 6 and Fig 7). 


\section{TURBIDITE Oued}

$$
\begin{aligned}
& 250.00 \\
& \text { 点 } 200.00
\end{aligned}
$$

$\begin{array}{llllllll}\text { P } 4 & \text { P } 5 & \text { P } 6 & \text { P } 7 & \text { P } 8 & \text { P } 9 & \text { Moy Max Min }\end{array}$

Points de Prélèvement

\section{DECEBRE $2016 \square$ AOUT $2017 \square$ MOYENNE}

Fig 6: Spatial evolution of turbidity means (NTU) measured in Oued waters

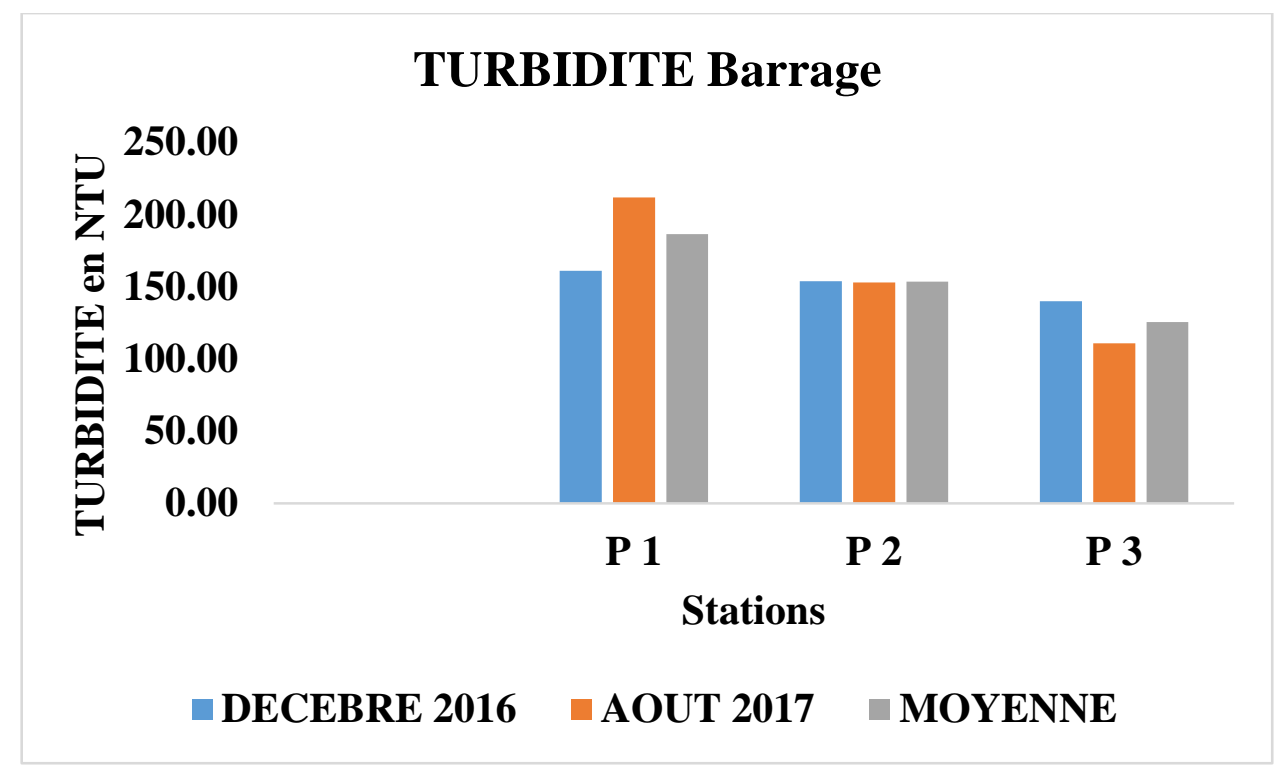

Fig 7: Spatial evolution of turbidity means (NTU) measured in dam water

\section{III.3. Azote}

Nitrogen levels in the study area vary between the maximum value of $8.88 \mathrm{mg} / \mathrm{L}$ and the lowest value of $0.56 \mathrm{mg} / 1 \mathrm{for}$ the Oued. For the dam, the nitrogen values vary between 3.28 and $4.53 \mathrm{mg} / 1$ for the samples taken in 2016, whereas the 2017 values vary between 2.45 and $14.54 \mathrm{mg} / \mathrm{L}$. 


\section{AZOTE Oued}

10.00



$\begin{array}{llllllll}\text { P } 4 & \text { P } 5 & \text { P } 6 & \text { P } 7 & \text { P } 8 & \text { P } 9 & \text { Moy Max Min }\end{array}$

Points de Prélèvement

\section{DECEBRE $2016 \square$ AOUT $2017 \square$ MOYENNE}

Fig 8: Spatial evolution of nitrogen averages measured in Oued waters

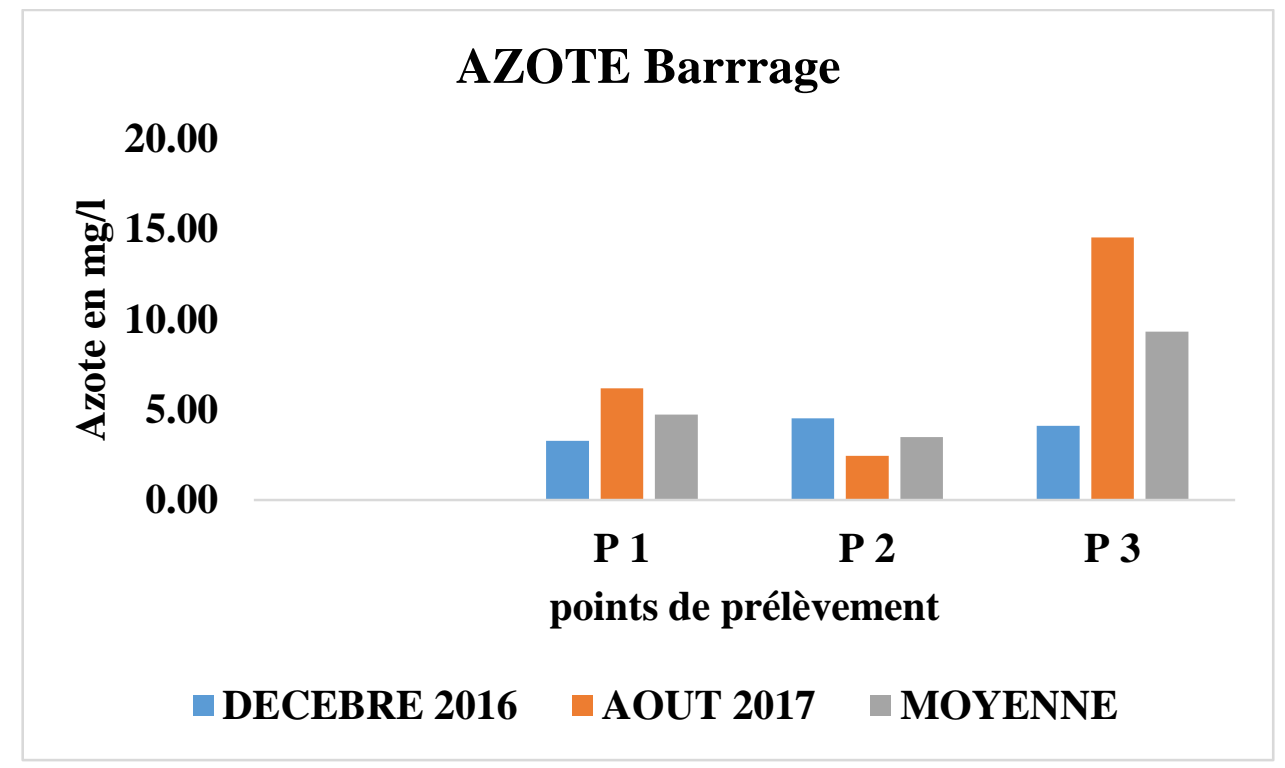

Fig 9: Spatial evolution of nitrogen averages measured in dam water

\section{III.4. Nitrite}

Nitrates and nitrites can be at the origin of various health complications such as irritations, allergies, abortions, cancers and chemical intoxications. Excess nitrites and nitrates can lead to severe anemia, especially in infants. [7]. Nitrites are considered to be intermediate ions between nitrates and ammoniacal nitrogen, which explains the low concentrations found in the aquatic environment. [13]. 


\section{NITRITE Oued}

12.000

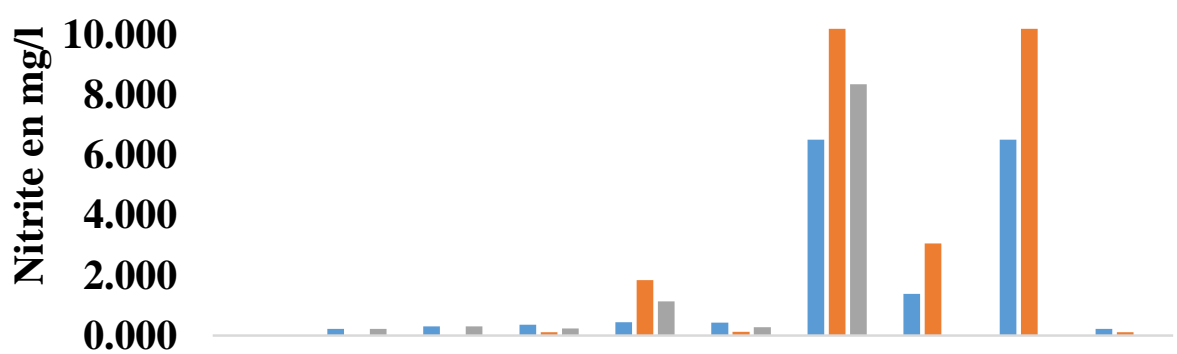

$\begin{array}{llllllll}\text { P } 4 & \text { P } 5 & \text { P } 6 & \text { P } 7 & \text { P } 8 & \text { P } 9 & \text { Moy Max Min }\end{array}$

Points de Prélèvement

DECEBRE $2016 \square$ AOUT $2017 \square$ MOYENNE

Fig10: Spatial evolution of nitrite means measured in Oued waters

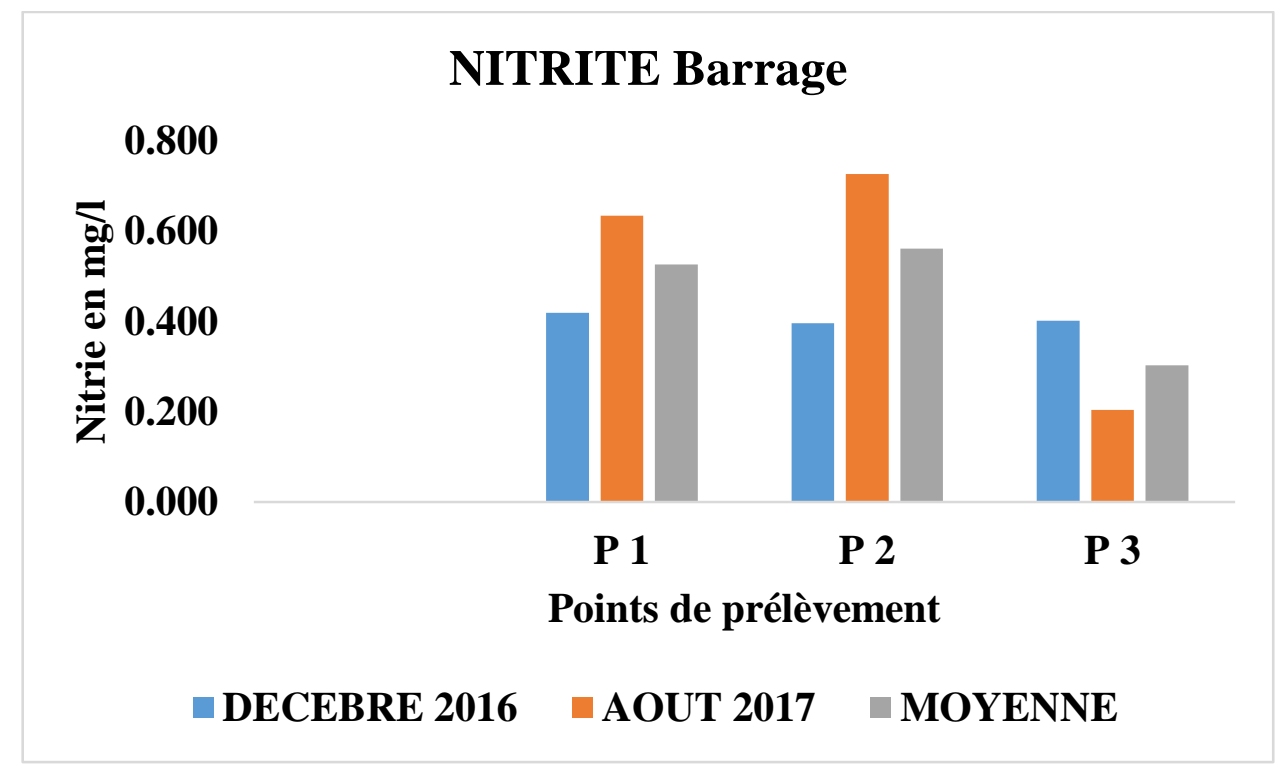

Fig 11: Spatial evolution of nitrite means measured in dam water

\section{III.5. Nitrate}

Nitrates are present in water by leaching of nitrogen products into the soil, by decomposition of organic matter or synthetic or natural fertilizers. Nitrate levels are highly variable with a mean maximum of $6.73 \mathrm{mg} / \mathrm{L}$ and a minimum of $0.299 \mathrm{mg} / 1$ at the Oued level (Fig 12). Then at the dam the minimum is $0.749 \mathrm{mg} / \mathrm{L}$ and maximum is $1.36 \mathrm{mg} / \mathrm{L}$. These values then make it possible to classify these waters in the middle class in class 2 (good) for the Oued whereas the waters of dam are classified in class 1 (Fig 13). 


\section{NITRATE Oued}

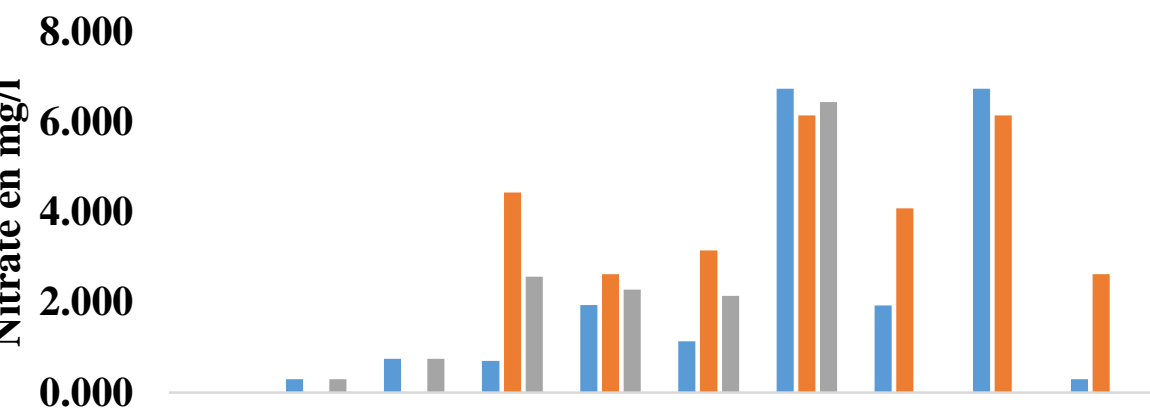

$\begin{array}{llllllll}\text { P } 4 & \text { P } 5 & \text { P } 6 & \text { P } 7 & \text { P } 8 & \text { P } 9 & \text { Moy Max Min }\end{array}$

Points de Prélèvement

\section{DECEBRE 2016 AOUT 2017 MOYENNE}

Fig 12: Spatial evolution of nitrate means measured in Oued Ouljat Echatt waters



Fig 13: Spatial evolution of nitrate means measured in dam water

\section{III.6. Ammonium $\mathrm{NH}_{4}^{+}$}

Ammonia nitrogen is one of the links in the complex nitrogen cycle in its original state. It is a gas soluble in water. The presence of ammonium ions in water is often a sign of degradation of organic matter in relation to the lack of available oxygen. It is a good indicator of pollution of watercourses by organic discharges of agricultural, domestic or industrial [13]. It is therefore a good indicator of the pollution of rivers by urban effluents [4]. 


\section{AMMONIUM Oued}
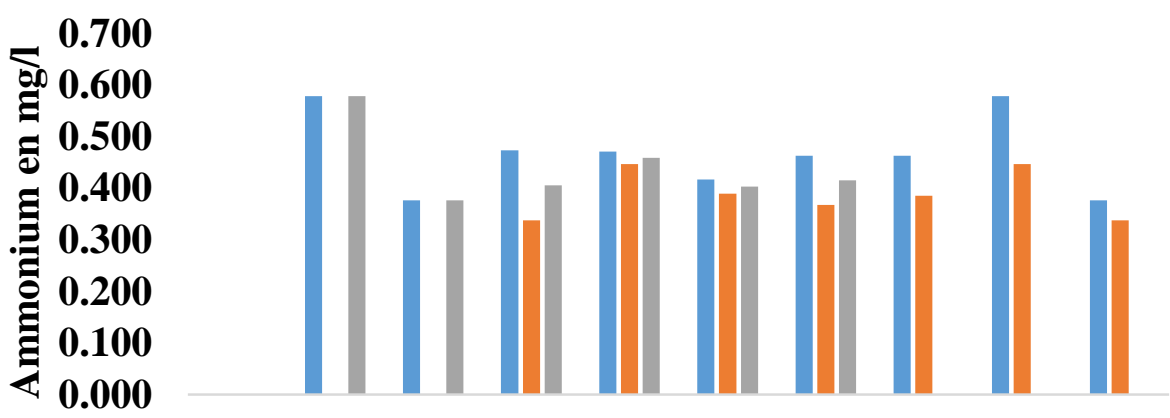

\section{$\begin{array}{llllllll}\text { P } 4 & \text { P } 5 & \text { P } 6 & \text { P } 7 & \text { P } 8 & \text { P } 9 & \text { Moy Max Min }\end{array}$}

Points de Prélèvement

\section{DECEBRE $2016 \square$ AOUT $2017 \square$ MOYENNE}

Fig 14: Spatial evolution of ammonium means measured in Oued waters

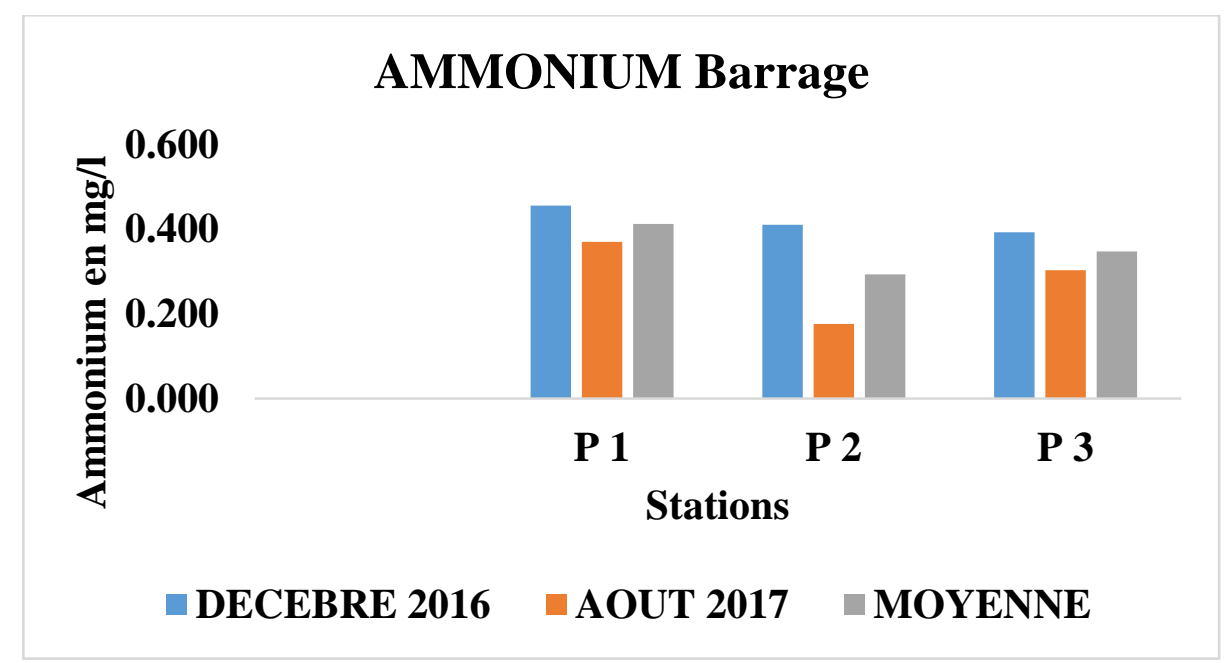

Fig 15: Spatial evolution of ammonium means measured in dam water

It shows a contamination of human or industrial origin [16]. Ammonia nitrogen is one of the links in the complex nitrogen cycle in its original state. It is a gas soluble in water.

\section{III.7. Phosphate}

In general, the excess of phosphates enters the water from sewage treatment plants and from the soil [18] too many phosphates can cause health problems, such as osteoporosis or problems with the kidneys [13] at Oued Ouljat Echatt. 


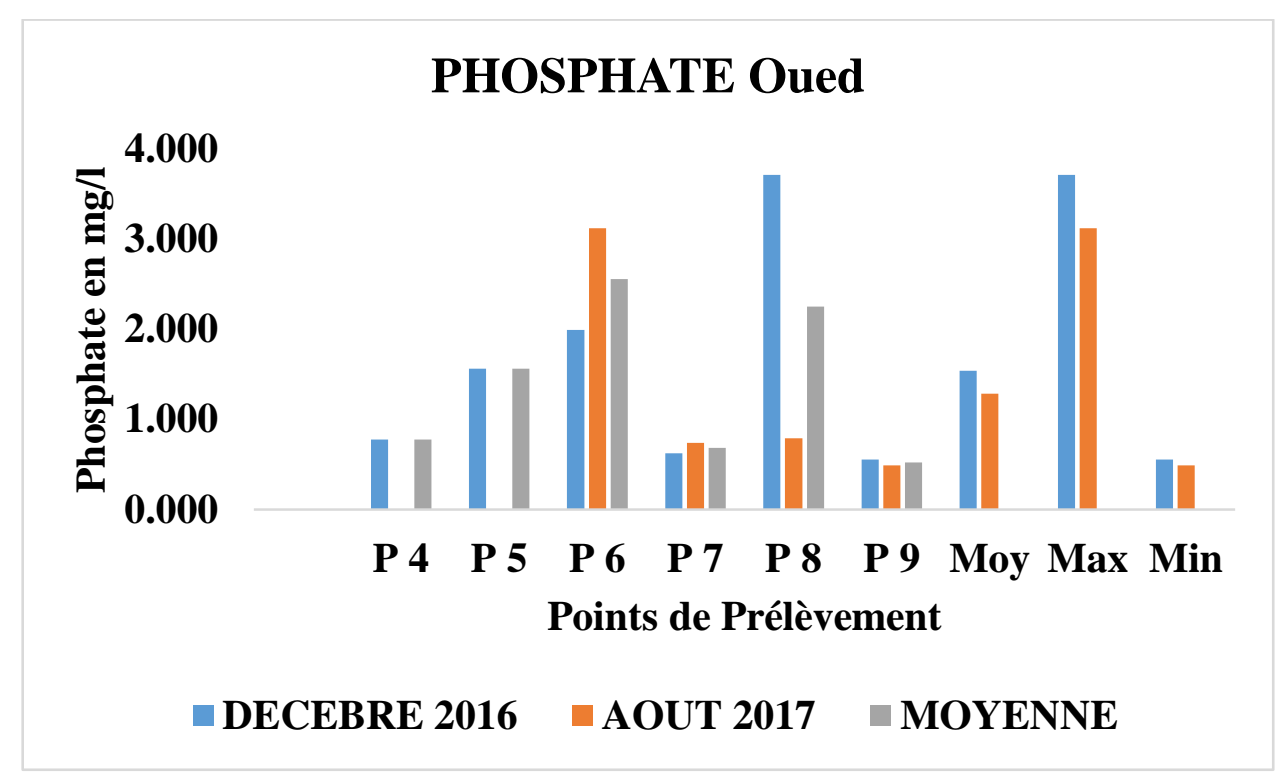

Fig 16: Spatial evolution of phosphate means measured in Oued waters

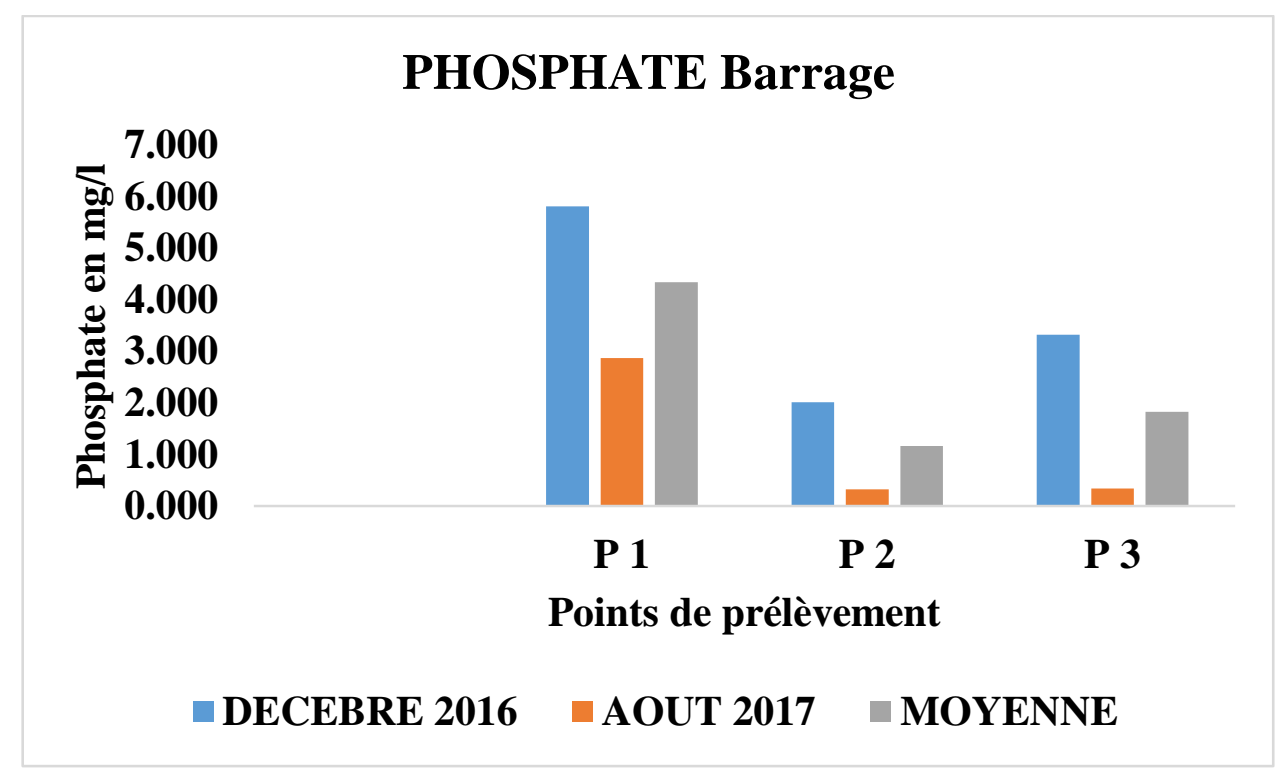

Fig 17: Spatial evolution of phosphate means measured in dam water

The phosphate contents oscillate between $0.489 \mathrm{mg} / \mathrm{L}$ at P9 at the exit of the STEP and $3.71 \mathrm{mg} / \mathrm{L}$ as the maximum value at P8, these grades make it possible to classify the Oued in class 4 (bad), similar contents are observed at the Ibn Batouta dam the phosphate content is low in general except at point P9.

\section{CONCLUSION}

The results described here suggest that it is possible to evaluate the physicochemical quality of the waters of Oued Ouljat Echatt and Ibn Batouta dam. In fact, the analyzes carried out on all the samples (along the river and at the dam level) show a significant degradation of the river waters. However, this degradation is less important at the dam level. This is due to blockages of river water by residents during periods of drought (including summer) for reuse in irrigation and watering animals. Otherwise the consequences will increase the degradation of the dam water. In this case, dam water can be classified in the middle class according to the standards of surface water and river water. To avoid the possibility of any health risk it is recommended to sensitize residents of the watercourse, its users and the local population. A bacteriological study is necessary to better clarify the state of Oued Ouljat Echatt and the Ibn Batouta dam. 


\section{REFERENCES:}

1. Abdoulaye D. 2013. Turbidité et matières en suspension dans l'eau : application a l'évaluation des métaux contenus dans l’eau de la rive droite du fleuve Sénégal. Larhyss Journal, ISSN 1112-3680, n²14, Juin 2013, pp. 93-105

2. Adjagodo A. et al. (2017) Pollution Physique Et Bactériologique De L'eau Du Fleuve Dans La Basse Vallée De L’Ouémé Pendant Les Périodes De Basses Et Hautes Eaux Au Bénin. European Scientific Journal November 2017 edition Vol.13, No.33 ISSN: 1857 - 7881 (Print) e - ISSN 1857- 7431

3. Boutayeb M. et al (2012). Etude de la qualité physico-chimique des eaux usées brutes de cinq villes de la région de la Chaouia - Ouardigha (Maroc) Bulletin de l'Institut Scientifique, Rabat, section Sciences de la Vie, $2012, \mathrm{n}^{\circ} 34(2)$, p. $145-150$

4. Derwich E., et al (2010). Caractérisation physico-chimique des eaux de la nappe alluviale du haut Sebou en aval de sa confluence avec oued Fès. Larhyss Journal, ISSN 1112-3680, nº 08, Juin 2010, pp. 101-112

5. Eblin S.G. (2014). Hydrochimie des eaux souterraines de la région d'adiaké (sud-est côtier de la côte d'ivoire). Larhyss Journal, ISSN 1112-3680, n¹7, Mars 2014, pp. 193-214

6. El Gharbaoui A, (1981). La terre et l'homme dans la péninsule tangitaine. Etude sur l'homme et le milieu dans le Rif occidental, Edi. Institut scientifique de Rabat, Service géologique et géographique, Rabat, Maroc, 439 p, 1981.

7. El Ouedghiri K. et al. (2014). Risques sanitaires liés aux composés chimiques contenus dans l'eau de boisson dans la ville de Fès : Cas des ions nitrates et nitrites. J. Mater. Environ. Sci. 5 (S1) (2014) 2284-2292. ISSN : 2028-2508

8. Koudenoukpo Z C et al. (2017) Caractérisation physico-chimique d'un système lotique en région tropicale : la rivière Sô au Sud- Bénin, Afrique de l'Ouest. Journal of Applied Biosciences 113: 11111-11122 ISSN 1997-5902

9. Laghzal A. et al. (2014). Contribution to the characterization of the physico chemical quality of water of some springs in the region of Tangier-Tetouan (Morocco). Larhyss Journal, ISSN 1112-3680, n²0, Décembre 2014, pp. 7-24

10. Mama D, et al, 2011. Étude dynamique des apports en éléments majeurs et nutritifs des eaux de la lagune de Porto-Novo (Sud-Bénin). Int J. Chem. Sci 5 (3) :1278-1293.

11. Mahamat S. et al 2015. Évaluation de la qualité physico-chimique des eaux d'adduction publique de la Société Tchadienne des Eaux à N'Djamena au Tchad. J. Appl. Biosci.

12. Michard A, (1976). Eléments de géologie marocaine. Editions du service géologique marocain, Rabat, 41p, 1976.

13. Mohamed Ben Abbou, et al (2014). Dégradation de la qualité des eaux de la nappe alluviale de l'Oued Larbaa par les déchets de la ville de Taza (Maroc). International Journal of Innovation and Scientific Research. ISSN 2351-8014 Vol. 10 No. 2 Oct. 2014, pp. 282-294

14. Nechad I et al. (2014). qualité physicochimique des eaux des sources Ain regrag et Ain sidi Bouali dans la région de Séfrou (moyen atlas, Maroc). Larhyss Journal, ISSN 1112-3680, n²0, Décembre 2014, pp. 127-146

15. Rifa N. et al, (2013). Modélisation des crues des rivières pour la gestion intégrée du risque d'inondation : cas du bassin versant de Tahdart (nord-ouest du Maroc). Revue des Sciences de l'Eau 27(1) (2014) 57-69. ISSN : 1718-8598

16. Rodier (J.) (2009)- L'analyse de l'eau : eaux naturelles, eaux résiduaires, eau de mer: chimie, physico-chimie, microbiologie, biologie, interprétation des résultats, $9^{\text {éme }}$ édition, Dunod, Paris, 1 (1959), 2009

17. Yassir T. et al, (2016). Etude Hydrogéologique préliminaire de la zone des flysch à l'Ouest de Tétouan (Maroc). International Journal of Innovation and Applied Studies. ISSN 2028-9324 Vol. 14 No. 3 Feb. 2016, pp. 653-667

18. Zerrouqi $\mathbf{Z}$ et al. (2013) Contribution à l'étude de la qualité des eaux de la lagune de Nador: Impact de l'anthropisation. Bulletin de l’Institut Scientifique de Rabat, Section Sciences de la Vie, 2013, n³5, 51-59 